\title{
Colombian Early Childhood Education and the Quest for Social Justice
}

\author{
Clara Ines Rubiano \\ Universidad Distrital Francisco José de Caldas, Bogotá, Colombia \\ Suzanne Flannery Quinn \\ University of Roehampton, Froebel College, London, UK
}

In this chapter, we provide a critical view of early childhood educational policy and some reflections on scenarios regarding 'what goes on' in Early Childhood Education and Care in Colombia today. We begin with an overview of the historical context of early childhood educational policies in Colombia together with a reflection on ideological discourses

embedded in their statements. This critical point of view serves as a basis to consider the field of early childhood education and care with regard to practices in the context of traditional and local scenarios and early childhood teacher education in Colombia. A common thread in the chapter relates to a social justice perspective regarding the lives of young children, their families, and the people that live and work with children. We suggest that new ways of thinking and reconceptualising early childhood education in the Colombian context may offer unique vantage points with respect to the tensions between rights based perspectives on early care and education and the instrumental and economic purposes that appear to underlie policy initiatives in Colombia and globally.

\section{Political and Historical Contexts}

Colombia is a land of infinite richness in its fauna, flora, geographical diversity and multi-ethnic population. It is a country that has also been known for its tradition of internal conflicts and violence due to fights for territorial control of drug production and trafficking (Jaramillo and Mesa, 2009) until recently. As a result of violence, guerrilla and armed conflict in the country, thousands of children of almost three generations have suffered from displacement of families, poverty and lack of schooling (Connolly et al., 2007, p. 51). It can 
be said that Colombia is also known as a nation full of good people who refuse to give up their dreams of peace which is not a free gift, but rather the result of the human capacity to construct social justice and combine it with solidarity (De Roux, 1998, p. 39).

\section{Colombia: A Demographic Sketch}

The Republic of Colombia is a transcontinental country, located in Northern South America, with territories in Central America. Colombia shares geo-political borders with Panama, Venezuela, Brazil, Ecuador, and Peru, and maritime limits with Costa Rica, Nicaragua, Honduras, Jamaica, the Dominican Republic, and Haiti. It is the only South American country with coastlines on both the Caribbean Sea and the North Pacific Ocean. According the World Bank (2013), Colombia is an upper middle-income country, with a gross national income of $\$ 6,110$ per person, and 37 percent of the population living below the poverty line. The population is approximately 47.12 million (CIA, 2017). As of 2013, the World Bank estimates are that more than 5.1 million children between 0 and 5 years of age live in Colombia, and that more than 50 percent of these children are poor. The UNDP Human Development Index, which is a measure of life expectancy, education, and income, places Colombia $87^{\text {th. }}$ in the world.

The CIA World Factbook (2017) indicates that while the birth rate in Colombia has fallen substantially since the 1960 s (from 6 per woman to 2.32 per woman), the population is increasing at a rate of $1.3 \%$ annually (just a little higher than the overall world growth rate) and the total dependency rate (which is generally based on the number of people below 14 and over 65 as a percentage of those between 15 and 64) is $45.6 \%$. Currently, Colombia could be considered to be in a period of demographic transition, as there has been a decline in fertility and population growth. However, profound income and socio-cultural inequalities persist, and there are large numbers of displaced persons due to decades of internal armed conflicts within the country. 
Vegas and Santibáñez (2010) report that there are approximately $20 \%$ of the population in Latin America and the Caribbean living below poverty, and that in some countries, the proportion of children experiencing poverty is more than $40 \%$. The region is second only to Sub-Saharan Africa in inequality of income distribution and other factors such as political influence and health and education outcomes (DeFerranti et al., 2003).

A comparison of infant and child mortality and other indicators of child health within the region (using data from the World Bank SABER Report Colombia, 2013) is presented in Table 1.

[Insert table 1 here]

The aforementioned factors have an impact on the complexities of life for young children and their families in Colombia and within the broader region of Latin America and the Caribbean. In particular, rates of poverty and prolonged internal armed conflicts have called attention to the need to consider the care and education of children in the context of inequalities and human rights. This perspective recognises that the care and education of young children in Colombia is situated within ideas and ideals regarding equity and justice (ideas based on human rights) but also within discourses that regard early care and education as services that are instrumental for economic aims (ideas based on human capital).

\section{Historical Perspectives}

The history of early childhood in Colombia begins from two different starting points. In the early twentieth century, two different institutions provided care, protection, and early education. One was public, and the other was private. El Hospicio de Bogota was the most important public institution working at recruiting orphaned or abandoned children. La Casa de los Niños del Gimnasio was the first private pre-school institution in the country (Jaramillo, 2009, p. 3). While the former was sponsored by the State and closed due to economic problems during the 1920s, the latter constituted the most important initiative to 
attend to the educational needs of young children by the private sector at the beginning of the century (Jamarillo, 2009, p. 4).

According to Jaramillo (2009), at that time, "there was an understanding that the political dispositions introduced through one of the first policy documents for early childhood (Decree 2101, 1939) were only valid to assess public institutions. These dispositions did not include any requirements or mechanisms to monitor or assess practices in private institutions. This particular issue initiated a tension between the public and the private sector"2 (Jaramillo, 2009 , p. 6) which over the years became a widening gap between the wealthy and the poor. This may have led to the proliferation of early childhood education or provision in the private sector.

\section{Policy developments}

In the 1970s, preschool education for children under six years of age was included as the first level of formal education (Decree No.088, 1976, Article 4). A decade later, the Curriculum for Early Childhood Education with a concept of comprehensive care for children and involving family and community, was designed and implemented (Decree No.1002, 1984). Later, in the 1990s, the 'Programa Grado Cero' [Zero Degree Programme, our translation] was created in coordination with the health sector and the Instituto Colombiano de Bienestar Familiar (ICBF), (the Colombian Family Welfare Institute, our translation). The programme was one of the results of proclaiming education as compulsory for children between five and seven years of age who were from marginalized urban sectors of large cities and rural areas (Constitución Nacional, 1991, Article 67; Ley 115, 1994). In the same decade, the national guidelines for preschool education were established and three stages were established for early childhood education: 'Pre-jardin' for 3-year-olds, 'Jardin' for 4-yearolds and 'Transicion' for five-year-olds (Decree 2247, 1997, Articles 2, 11, 12, 13). The political actions legislated over the nineties were permeated by a public policy document 'El 
Tiempo de los Ninos' [Children's Time, our translation] which aimed at contributing to the welfare of young children by providing nutrition, health and education programmes for the poorest and most vulnerable children in the country (CONPES 2787, 1995). In the last decade, the public national policy 'Colombia for Early Childhood' (CONPES, 2007) was enacted in tune with the goals and strategies for early childhood in the Millennium Plan (CONPES 091, 2005) which aimed at eradicating extreme poverty and reducing child mortality.

Colombia, is one of the nineteen Latin American countries ${ }^{1}$ committed to achieve a better future for children. Taking into consideration the first goal of Education for All, "expanding and improving comprehensive early childhood care and education, especially for the most vulnerable and disadvantaged children" (UNESCO, 2010, p. 19), the country as well as its nation sisters in the region, has developed integrated programmes for the Protection and Care for the most vulnerable populations of children in each country. Table 2 shows information from Bernal and Camacho's (2010) comparison of some relevant Early Childhood Comprehensive Attention and Care programmes in Latin America:

[Insert Table 2 here]

Internationally, Colombia has been recognized as a country whose search for social justice is reflected in its programmes and projects that target the most vulnerable population of children as well as displaced and relocated populations (UNESCO, 2006, p. 7).

Programmes such as 'Social Kindergartens', 'Good Start', 'Childhood and Quality of Life', Family Education for Childhood Development (PEFADI), Family, Women, and Childhood (FAMI), Education, Health, and Environmental Improvement (PROMESA), Hogares Comunitarios de Bienestar (HCB), and Community Welfare Homes and Children's homes have been used as meaningful experiences for other agencies and countries in the region 
(UNICEF \& CINDE, 2001, p. 7). As a result, the nation launched the Early Childhood Education Policy (ECEP) in 2009.

The ECEP (MEN, 2009) is embedded in the context of fundamental rights of children: health, education, nutrition, protection, and participation. These fundamental rights have been identified as the core constituents of the National Public Policy 'Colombia por la Primera Infancia' [Colombia for Early Childhood, our translation] (MEN, 2009, p. 30). This national initiative aims to promote the comprehensive development of children, from conception to age six years, through meeting their needs and specific characteristics with the hope of achieving equity and social inclusion in the nation (CONPES, 2007, p. 28). The ECEP is incorporated in the social protection system focused on strengthening human capital and at assisting individuals in conditions of poverty and social vulnerability (CONPES, 2007, pp. 25-29). In this frame of reference, this educational policy aims at providing adequate care to children during their early age in order for them to have better chances for joining formal education on time, be more successful in their studies, improve their access to higher education, and increase their opportunities for performing competently in their professional lives (MEN, 2009). From this vantage point, the ECEP may be best understood as a political initiative that strives to foster equity and inclusion for vulnerable and socially disadvantaged children in the country.

In a context of equity and social inclusion as rights, it seems that the ECEP resonates with @ the Universal Declaration of Human Rights (UDHR), where education constitutes a good that opens, builds up, empowers, and states other rights@ (UDHR in Gentili, 2009, p 20). In this vein, Colombia, as a South American nation demonstrates a greater visibility of early childhood on public policy agendas and increases recognition of children as subjects with rights (UNESCO, 2010, p. 16). However, it can also be said that the country may be facing the challenge of overcoming the gap between the discourse stated in the legal 
framework and the everyday practice that ensure the rights of children (UNESCO, 2010). In other words, “... agreements, declarations and treaties on human rights ... are marked by the abysmal asymmetry between their underlying foundations and the actions and practices that should enshrine them [our translation" (Gentili, 2009, p. 21).On the one hand, it could be argued that the quest for social justice perceived in the ECEP (MEN, 2009) is politically mediated by local and social policy plans in accordance with global goals and agendas on early childhood education and care. On the other hand, it seems that the political dispositions subsume ideological discourses that may alienate the search for social justice and equity as rights for younger human beings. In this sense, it may be useful to consider discourses that may cause a disruption between the foundations on social justice and equity as rights stated in the ECEP, and the quality of the provision of the service in the everyday life of Colombian children.

In what follows, we concentrate our attention on this political initiative to reflect on the ideological discourses, but it is worth mentioning that the State Policy for the comprehensive development of early childhood 'De Cero a Siempre' (From Zero to Forever) was recently enacted in law (Ley 1804, 2016).

\section{Ideological discourses}

A discourse of 'a culture of poverty' can be perceived in the Colombian policy statements for early childhood. Assertions such as "comprehensive early childhood education and care for the most vulnerable and disadvantaged children" (UNESCO, 2010, p.10), "education compulsory for children between five and seven years old belonging to marginalized urban sectors and rural areas" (CONPES 091, 1995), "plans assisting human beings in conditions of poverty and social vulnerability (CONPES, 2007, p. 29) and "goals eradicating extreme poverty" (CONPES 091, 2005) demonstrate this. The appeal to 
perpetuate the distinction between poor and rich in the country seems to be used as what Penn (2005) describes as a strategy that targets interventions on young children who are experiencing poverty. These strategies are designed to provide skills for young people to bring themselves out of poverty, without a recognition of the broader mechanisms of poverty that permeate the economy.

In the Colombian socio-cultural context, the discourse of a 'culture of poverty' could be counterproductive to the extent that education could be intricate in a kind of postfigurative culture (Mead, 1970, p. 17) of the endless crisis in Latin-American educational systems which have received the impact of the neoliberal globalization focused on the link between education and work (Torres, 2008). This assumption can be envisaged in early childhood practitioners' perceptions, such as:

I dream with a whole family ruled by love and trust, with a free Colombia, with large schools with spacious classrooms well equipped and outdoors - recreational areas ... I cannot be in peace because questions disturb me: for how long will I be working? Why aren't things clear and transparent? Corruption, influence peddling and politics are ending up with public education [our translation] $]^{3}$ (Mieles-Barrera et al, 2009, p. 55).

This perception of education suggests that publicly funded early childhood education and services are scenarios without hope.

Furthermore, the ECEP (MEN, 2009) promulgates explicitly a child development perspective in which "All children, regardless of the socio-cultural context in which they grow, have the capabilities of developing their competencies if they find an environment that meets their basic needs for affection, care and feeding" (MEN, 2009).

A possible 'discourse of universality' which refers to the 'set of arguments concerning child development or the uses of it which is intended to put into policy and 
practice' (Penn, 2008, p. 7) can be perceived in the previous statement. From our point of view, one issue is that the ECEP (MEN, 2009) embraces policy statements on equity and access to education for all children, but there is paradox in that it also aims to enact mandates on child development for all, which applies a universal standard of development for all children.

We argue that this discourse is evident in the government guidelines for early childhood education. For example, as translated from the UNESCO report (2006) the objectives and aims of early education in Colombia are articulated in generic terms with an emphasis on (presumably universal) developmental norms and academic 'readiness', in objectives such as:

- knowledge of one's own body and its capabilities; and the development of identity and autonomy

- harmonious and balanced growth to facilitate motor development, readiness and motivation for reading and writing and for solving problems that involve mathematical relation and operations

- development of age-appropriate creativity, skills and abilities, and of learning capacity; - a sense of space and time and the exercise of memory;

- development of the ability to learn forms of expression, relation and communication and to establish relations of reciprocity and participation, observing rules of respect, solidarity and coexistence;

- participation in play activities with other children and adults;

- stimulation of curiosity to observe and explore the natural, family and social environment; - recognition of the spiritual dimension as a rationale for criteria of conduct;

- engagement of the family and community in the educational process in order to improve the quality of life of the children in them; and 
- formation of habits with regard to eating, personal hygiene, cleanliness and tidiness in order to create an awareness of the value and necessity of health (UNESCO, 2006)

The recommended learning areas and teaching and learning methods are based on generic notions of the 'whole child'(recognisinig the child, as a pupil, who is a unique person within the ecological system of their family and the natural, social, and cultural environment); the importance of participation (to build a sense of belonging and group commitment), and 'play' as a 'dynamic force in children's lives, through which they build knowledge, discover themselves and the physical and social worlds, develop their initiatives, share their interests, develop communications skills, and build and internalize rules" (UNESCO, 2006). UNESCO's notion of play also recognises that play is a source of enjoyment and an inspiration as well as an expression of creativity that helps children to make meaning within a natural, social, and cultural context.

In these curriculum objectives and principles of teaching we can read generic and 'universal' concepts of child development and play. These concepts, which make reference to children's rights appear to have sensitivity to young children's concerns. However, these statements are devoid of any consideration of how to incorporate them in the context of economic and political uncertainties and profound inequalities, or in situations where there is a threat of violence due to internal armed conflicts and displacement. These issues should be considered in light of the diverse lived experiences of young people and their families in the Colombian context.

This discourse of child development is articulated in the ECEP with statements such as: 'there are always pre-conditions from which children construct knowledge, and children develop knowledge that allows them to 'do', then to 'know how' and finally to 'be able to do' “(MEN, 2009). In addition, “practitioners are supposed to generate meaningful educative spaces in which children recreate and play dialogues with others" (MEN, 2009). From this 
perspective on child development and teaching methodology, the discourse of universality may deny the "adverse influences on child development" (White and Isenberg, 2003, p. 18) in a context in which the realities of the daily lives of children in relation to the effects of globalization and neo-liberal educational policies are ignored. Torres (2008) explains that globalized educational mandates do not consider the real lives of children and families who experience narcotraffic and displacement due to violence and warfare. Besides, this ideological discourse may restrict the freedom on the principles of social justice and equity and may limit the control of the quality in the provision of early childhood services to policy makers.

A discourse of 'managerialist control' can also be perceived in the political statements regarding the concept of 'quality' on the principles of equity, social inclusion, and comprehensive care in the Colombian early childhood education policy. Evetts (2009) describes managerialism as a form of organisation and professionalism that "incorporates rational-legal forms of authority and hierarchical structures of responsibility” (p. 23) resulting in increased standardization of work that comes to rely on external forms of control through regulation and accountability.

This panorama can be translated into the provision of early childhood services by the Ministry of Education and the ICBF in which they develop programmes and projects to provide comprehensive development for Colombian children in partnership with the Municipalities (MEN, 2009). In this scenario, quality refers to the number of children immersed in those programmes or projects, infrastructure, comprehensive development and budget execution by the responsible authority, in this case, governors, mayors, and education and health secretaries in the regions (MEN, 2009).

Furthermore, quality is also associated with the 'Planes de Acción Integral' [Comprehensive Action Plans, our translation] that are meant to generate participation and 
reflection on the quality of early childhood education and at the same time seen as tools to strengthen the standardization of work procedures and practices in the field of early childhood (MEN, 2009). In terms of accountability, the Ministry of Education and the ICBF are encouraging Higher Education institutions to participate and carry out research projects to measure the impact of their programmes (e.g. Bernal \& Camacho, 2010).

At this point, it could be said that 'quality' in the provision of early childhood education may serve as a concept of political power rather than "a questionable concept, a problem that needs to be explored ..."(Urban, 2008, p. 138). It can also be argued that this kind of discourse may empower the mercantilist view of education in which 'quality' refers to the demand and supply of the provision of early childhood services.

It could be surmised that this critical view on early childhood educational policy may serve as a basis to consider the field of early childhood in terms of 'what goes on' in early childhood education with regard to customs, practices in traditional and local scenarios , and early childhood teacher education in Colombia.

\section{Scenarios: 'What goes on' in Early Childhood Education in Colombia}

At the international level, Colombia has demonstrated achievements such as the enrollment of children from birth to five year olds which has more than doubled between 2007 and 2013, from 16\% to 41\%. The 'Cero a Siempre' strategy is another achievement which was the result of a nationwide consultation process, and provides a holistic framework for children's well-being and development, and sets clear standards for the provision of education services. Considerable efforts have focussed on setting higher standards for the profession and upgrading the skills of ECEC staff, many of whom are community mothers (OECD, 2016).

Framed in the context of fundamental rights of children as well as the ECEP (MEN, 2009), the comprehensive development of Early Childhood 'Cero a Siempre' State policy 
(Law 1804, 2016) is based on the general principles of the Colombian Political Constitution (1991), the Childhood and Infant Code (Law, 1098, 2006) and national and International adjacent laws. It confirms the ten principles stated in the Convention of the Rights of the Child (UN, 1989) giving emphasis to the recognition of rights without exception, difference or discrimination without cause, protection of freedom and human dignity and the highest interest of the child (Law 1804, Article 3, 2016).

The Colombian State through the 'Cero a Siempre' law (Law 1804, 2016) is committed to guarantee the conditions for every child with regard to promoting that the child:

- Live with a father, mother, relatives or main carers that may implement upbringing and parenting for child comprehensive development

- Live and enjoy his/her highest health level

- Enjoy and keep an adequate nutritional status

- Grow up in environments that promote his/her development

- Build up his/her identity framed in diversity

- Express his/her feelings, ideas and opinions in daily situations that guarantee to be heard.

- Grow up in conditions that guarantee their rights and act accordingly in situations of risk and vulnerability.

Internationally, the OECD (2016) estimates that many children do not participate in ECEC in the Colombian context. In 2013, only $48 \%$ of 3-year-olds and $75 \%$ of 4-year-olds were enrolled, compared to the OECD average of $70 \%$ and $82 \%$ respectively. Only $63 \%$ of children transition to schools at the right age. Late enrolment is both detrimental to learning and more costly for the system. Young children from disadvantaged families are likely to attend low quality modalities or not to have access to ECEC at all. Together with poor home 
learning environments, this hampers their chances of progressing adequately through the education system and breaking out of the cycle of poverty.

\section{Modalities and Scenarios of Early Childhood Education and Care in Colombia}

In Colombia, early childhood education can be seen in two main modalities. One modality is comprised of care programmes led by the Colombian Institute of Family Welfare (ICBF) and other institutions such as the Administrative Department of Social Welfare of the District in Bogota, NGOs, and other private organisations. The other modality includes preschool (or pre-primary education) regulated by the educational sector and offered by official and private schools. Table 3 presents information on programmes and modalities using data provided by Fernandes et al (2006).

[Insert Table 3 here]

Evaluation studies of early childhood education and family programmes in Colombia and within the Latin American region have found benefits related to gains in children's cognitive abilities and overall increased effects on children's health (Araujo, López-Boo \& Puyana, 2013; Attanasio, Di Maro, \& VeraHernández, 2010). Early results have found positive nutritional outcomes in conditional cash transfer programmes such as Familias en Acción, as well as nutritional and educational benefits associated with Hogares Comunitarios de Bienestar in Colombia.

Colombian policy documents also describe early childhood education and care services in two modalities (MinEducacion, 2014). One is centre-based (institutional) and the other is home-based (education and care of children in their homes) The centre-based modality has an aim to provide comprehensive care through education with professional educators who are responsible for upholding children's rights to education, and who are not thought of as working alone in this endeavour, as they are to be supported by the State as well as families, whose participation in the centres is required. The home-based modality is aimed 
at strengthening families as they nourish the potentials of children (boys and girls), particularly the youngest children (under the age of 2). Home-based modalities of early care and education are built on the view of the family as the starting point and are designed to support people in a range of geographic environments, as well as diverse social, cultural, and economic situations. Services for young children and their families in both modalities involve comprehensive education and health care, as well as family support through education and activities for children to experience enjoyment and learning. All professionals must guarantee these services.

\section{Global interventions}

As a result of a focus on the 'poorest' families and the ideological discourses of the culture of poverty in Colombia, many of the early childhood programmes that are visible (from outside of Colombia) have an emphasis on services for children in rural and poor areas in line with the initiatives of global institutions or NGOs such as UNICEF. Specific programmes include the 'Integrated intervention targeted at deprived preschool children', 'Corporacion educative huellas de la esperanza', and a social enterprise programme, aeioTu.

The above programmes (highlighted on web pages such as educationinnovations.org) give a perspective on Colombian early childhood education that focus on child development perspectives (cognitive, verbal, motor skills, parent-child interactions, understanding and awareness of nutrition and support for pregnant women), generic 'play-based' learning (through books, puzzles, and toys), and first-hand experiences like gardening and taking care of animals (UNICEF). One programme (aeioTu) articulates that their approach is inspired by a European model. A longitudinal evaluation of aeioTU is planned (see the NIEER web page, http://nieer.org/document/aeiotu).

\section{Views from early childhood teacher education}


We must look beyond these highly visible generic and outsider scenarios of early education in Colombia, with models based on the Global North, to better understand what we can learn from Colombian sensitivities with regard to the lives of young children and those who live and work with young people. As articulated by Tapiero (2014):

Los escenarios en los que se desarrolla la Vivencia Escolar contribuyen en la consolidación de un concepto amplio de Infancia, en el que asume su diversidad histórica y cultural, por ello no adopta una única versión de estadios o etapas de desarrollo del niño, de edades y grados de escolaridad como aproximación de interpretación/comprensión de las problemáticas y realidades de la infancia. The scenarios in which the school's experience (as a co-existence with other aspects of life) contribute to the consolidation of a wider concept of early childhood, which embraces its historical and cultural diversity, but it does not adopt a restricted version of child development stages in terms of age, or school level as an approximation for the interpretation or understanding of problems and realities of early childhood' (Tapiero, 2014; our translation).

This insider view provides insights from the practicum component of an early childhood teacher education programme from the lens of an experienced early childhood educator who has transformed the experience of the practitioner to the sensitive person who dares to live the experience with children from the co-existence scenario of practices and pedagogy.

\section{The Teaching Profession in Colombia}

Colombian teacher education and subsequently early childhood teacher education seem to be involved in the process of global change that has inspired educational policies promoting reforms in education. For instance, while some countries appear to prioritize the analysis of circumstances where education has become more critical for the future success of nations because of the urgent speed of change (Townsend, 2011, p. 373), other nations in Latin America seem to concentrate on educational sovereignty, as an exercise of freedom and resistance that acknowledges the democratizing power of education in the continent (Puiggrós, 2010, p. 19). In this dynamic of global change, teacher education has not been static in any country (Menter, Brisard \& Smith, 2006, p.82). 
Colombian teacher education has been characterized by its open disposition to international trends in education aimed at strengthening the teaching profession (UNESCO, 1998; 2005). Specifically, early childhood teacher education (ECTE) is embedded in general educational mandates and trends which promote institutional growth, encouraging capacity to struggle against adversity and inspiring pedagogical ideals to fight for education as hope for the future of the nation. Despite this, there is also a pervasive oppression in early childhood education that leads to a hierarchical oppression "in which dominant or privileged groups reap advantage, from the disempowerment of targeted groups” (Adams, Bell \& Griffing, 2007, p. 5). The hierarchical relationship between the Colombian State and teachers' professionalism becomes the main example of this kind of oppression. The professionalisation of Colombian teacher education has been constructed by decree or "from the above" (Evetts et al., 2009, p. 22). It has been the main organising principle for the public service of education through the implementation of "legal forms of authority, increased standardisation of work procedures and practices, regulation, and accountability measures" (Evetts et al., 2009, p. 23) (e.g. Decree 1278, 2002; Decree 3782, 2007; Decree 2715, 2009). This emphasis on "teacher standards places early childhood teachers as objects for measurement" (Sachs, 2005, p. 2) and denotes a dominant force on the teaching profession which leads to the disempowerment of teachers to co-create a collective identity towards an equitable Colombian society.

The disempowerment of teachers nurtures an internalised oppression which "not only resides in external social institutions and norms but lodges in the human psyche as well" (Adams, Bell \& Griffing , 2007, p. 5). This internalised assumption allows the dominant group, in this case the Colombian government, to introduce the "massive technological training of tutors and the involvement of the philanthropic services" in teacher education 
(MEN, 2002) dwindling the teachers' sense of humanization of education through defining the future of the profession collectively (Freire in Schugurensky, 2011, p. 205).

It could be argued that power relations regarding local and global change in educational policy reforms subsume the 'new' tensions in Colombian teacher education and subsequently early childhood teacher education.

\section{Challenges in the quest for Social Justice in Early Childhood Education}

The awareness of the existence of the power of ideological discourses in Colombian early childhood education presupposes challenges for the early childhood teaching profession. These challenges in the search of social justice and equity seem to be mainly related to the construction of new discourses in which:

Different tomorrows are possible. The struggle is no longer reduced to either delaying what is to come or ensuring its arrival; it is necessary to reinvent the future. Education is indispensable for this reinvention. By accepting ourselves as active subjects and objects of history, we become beings who make division. It makes us ethical beings (Freire, 2006, p. 55).

This reinvention implies being involved in a journey of transformation in which early childhood educators build up a framework of action with new discourses, different perceptions on the causes of poverty, new approaches of studying early childhood development and other views on professionalism.

Discourses such as the one on the perception of the causes of poverty illustrated by Penn (2005) in which 'poverty causes a culture which limits escape from poverty, and as a result, people are and remain poor because of their beliefs, attitudes, and behaviours (Penn, 2005, 27), may lead to emphasise a postfigurative system (Mead, 1970, p. 40) of the culture of poverty. Therefore, we argue that this calls our attention to reconsider the ways we are thinking and talking about early childhood education. For example, we might consider new 
ways of thinking about early childhood development that has a focus on children's lived experiences, their behaviour and the invisible issues such as practitioners different perceptions and interpretations of 'what is going on' in the lives of children and their families. This could suggest that professional practice might be based on a co-existence of children and practitioners, which could shift the role of practitioner to one that would be better described as 'vivencialista' (Tapiero, 2014). This term in Spanish has the connotation of an early childhood educator who lives in co-existence with children and with the awareness of children's daily problems and challenges and who is concerned with children's life projects (e.g. Ramirez and Escorcia, 2007). This may provoke a sense of openness in the lives of people who live and work with children.

Moreover, new discourses on professionalism as "the development of critical dispositions in the struggle for social justice and care" (Cannella, 2002, p. 167) may lead vivencialistas to "learn to interrogate the social, cultural, linguistic, and power context in which their belief structures and educational practices have been constructed" (Cannella.,2002, p. 168). The existence of new discourses introduces new dynamics to the struggle for an equitable and just society for Colombian children and provides a new dimension for early childhood educators as ethical beings in pursuing social justice and equity as rights for children.

\section{Summary}

The previous reflections demonstrate that there is a general commitment from the Colombian government towards promoting comprehensive early childhood care and education in policy documents. However, in our contemplation, we suggest that discourses on social differences, generalizations on child development and organizational professionalism embedded in the foundations of these political initiatives, could undermine the quest for social justice and equity as rights for children. The awareness of the challenges in the pursuit 
of social justice in early childhood education can be understood as the generative force for reconceptualising the field. The construction of new discourses on early childhood care and education can become a new challenge for teacher education and the struggle for social justice, with lessons learnt from the Colombian context.

\section{References}

Adams, M., Bell, L. A. and Griffing, P. (eds.) (2007) Teaching for Diversity and Social Justice. Second Edition. London: Routledge.

Araujo,M. C., López-Boo, F., \& Puyana, J. M. (2013). Overview of early childhood services in Latin America and the Caribbean. New York: Inter-American Development Bank.

Attanasio, O., Di Maro, V. \& VeraHernández, M. (2010). Community nurseries and the nutritional status of poor children. Evidence from Colombia. Documento de trabajo inédito. London: Institute of Fiscal Studies.

Alderson, P. (2005) 'Children's Rights. A new approach to studying childhood', in Penn, H. Understanding Early Childhood. Issues and controversies. Glasgow: Open University Press, pp. 127-141.

Bernal, R. and Camacho, A. (2010) La importancia de los programas para la primera infancia en Colombia. Retrieved from:

https://economia.uniandes.edu.co/components/com_booklibrary/ebooks/dcede201020.pdf [The relevance of early childhood programmes in Colombia, our translation].

Cannella, G. (2002) Reconceptualizing Early Education as the Struggle for Social Justice. Deconstructing Early Childhood Education. New York: Peter Lang.

Central Inteligence Agency (2017). Colombia. In The world factbook. Retrieved from: https://www.cia.gov/library/publications/the-world-factbook/geos/co.html

Connolly, P., Hayden, J. and Levin, D. (2007) From Conflict to peace building: the power of Early Childhood Initiatives. Lessons from around the world. Project report of the 
World Forum Foundation. Retrieved from: http://s3.amazonaws.com/ineeassets/resources/WF_Peacebook_chap0intro.pdf

CONPES (2007) Política Pública Nacional de Primera Infancia: 'Colombia por la Primera Infancia'. Retrieved from: https://www.mineducacion.gov.co/1759/articles177832_archivo_pdf_Conpes_109.pdf [National Public Policy for Early Childhood: 'Colombia for Early Childhood', our translation].

CONPES 091 (2005) Documento de Política para cumplir con las Metas del Milenio. Presidencia de la República de Colombia. Retrieved from: http://www.minambiente.gov.co/images/normativa/conpes/2005/Conpes_0091 2005.pdf [Policy Paper to meet the Millennium Development Goals, our translation].

CONPES 2787 (1995) El tiempo de los niños. Retrieved from: http://www.icbf.gov.co/cargues/avance/docs/conpes_dnp_2787_1995.htm [Children's Time, our translation].

Constitución Nacional (1991) Constitución Política de Colombia. Retrieved from: http://www.corteconstitucional.gov.co/inicio/Constitucion\%20politica\%20de\%20Col ombia\%20-\%202015.pdf [Political Constitution of Colombia, our translation]. Decree 088 (1976) Reestructura del Sistema educativo y se organiza el Ministerio de Educación Nacional. Retrieved from: http://www.mineducacion.gov.co/1621/articles102584_archivo_pdf.pdf [Restructures the Educational System and organizes the Ministry of Education, our translation].

Decree 1002 (1984) Establece el Plan de Estudios Para la Educación Preescolar, Básica (Primaria y Secundaria) y Media Vocacional de la Educación Formal Colombiana. Retrieved from: http://www.mineducacion.gov.co/1759/articles103663 archivo_pdf.pdf [Establishes the curriculum for Preschool, Basic (Primary 
and Secondary) and Media Vocational Education levels in the Colombian Formal Education, our translation].

Decree 1278 (2002) Estatuto de profesionalización docente. Ministerio de Educacion Nacional. Retrieved from: http://www.mineducacion.gov.co/1621/articles-

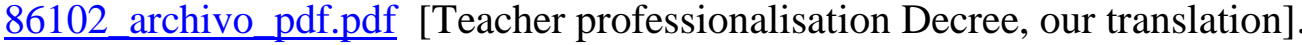

Decree 2247 (1997) Establece normas relativas a la prestación del servicio educativo del nivel preescolar. Retrieved from: http://www.siteal.iipe.unesco.org/sites/default/files/col-_preescolar.pdf [Establishes the standards on the provision of educational services at preschool level, our translation].

Decree 2715 (2009) Reglamenta la evaluacion por competencias de los docentes y directivos docentes. Ministerio de Educacion Nacional. Retrieved from: http://www.mineducacion.gov.co/1621/articles197108_archivo_pdf_decreto_2715.pdf

Decree 3782 (2007) Reglamenta la evaluacion anual de desempeno laboral de los servidores publicos docentes y directivos docentes. Retrieved from: http://www.mineducacion.gov.co/1621/articles-135430_archivo_pdf.pdf [Regulations for annual state teachers and administrative teachers' job performance evaluation, our translation].

De Ferranti, D., G. Perry, F. Ferreira, and M. Walton. (2003). Inequality in Latin America and the Caribbean. Breaking with History? Washington, DC: World Bank.

De Roux, G. (1998) ‘An invitation for Peace’. In Fals-Borda, O. People’s participation: challenges ahead. (Compiled and Analysed) Bogota: Tercer Mundo Editores, S. A. pp. 37-42. 
Evetts, J. (2009) 'The Management of professionalism. A contemporary paradox', in Gewirtz, S., Mahony, P., Hextall, I., and Cribb, A. (eds.) Changing Teacher Professionalism. International trends, challenges and ways forward. London and New York: Routledge, pp. 19-30.

Fernandes, I., Villa, L., Castaño-Mesa, L. and Díaz-Matajira, L. (2006) Situación de la Educación Preescolar, Básica, Media y Superior en Colombia. Segunda Edición. EDUCACIÓN compromiso de todos. Casa Editorial El Tiempo.[Situation of Preschool, Basic, Middle and Higher Education in Colombia. Second Edition, our translation].

Freire, P. (2006) Pedagogy of the Heart. New York; London: Continuum.

Gentili, P. (2009) 'Marchas y Contramarchas. El derecho a la educación y las dinámicas de inclusión excluyente en América Latina'. Revista Iberoamericana de Educación. $\mathrm{N}^{\circ}$ 49, pp. 19-57. [Marchs and Countermarchs. The Right to Education and the dynamics of exclusionary inclusion in Latin America, our translation].

Jaramillo, L. (2009) Antecedentes históricos de la educación preescolar en Colombia. Retrieved from: http://ylanglang.uninorte.edu.co:8080/drupal/files/AntecendentesHstoricosEducacionColombia.p df [Historical background of preschool education in Colombia, our translation]. Jaramillo, R. and Mesa, J. (2009) Citizenship education as a response to Colombia's social and political context. Journal of Moral Education, 38(4), pp. 467-487.

Ley 115 (1994) Por el cual se expide la Ley General en Educación. Retrieved from: http://www.mineducacion.gov.co/1621/articles-85906_archivo_pdf.pdf [Decree in which the general education law is issued, our translation].

Ley 1804 (2016). La política de estado para el desarrollo integral de la primera infancia De Cero a Siempre. [State policy for the comprehensive development of early childhood 
Zero to forever, our translation]. Retrieved

from: http://es.presidencia.gov.co/normativa/normativa/LEY\%201804\%20DEL\%200 2\%20DE\%20AGOSTO\%20DE\%202016.pdf

Mead, M. (1970) Culture and Commitment. The new relationships between the generations in the 1970s. London: Bodley Head

MEN (Ministerio de Educación Nacional) (2002) La Revolucion Educativa. Ministerio de Educacion Nacional. Retrieved from: http://www.mineducacion.gov.co/1621/articles85266_archivo_pdf.pdf [The Educational Revolution Policy, our translation].

MEN (Ministerio de Educación Nacional) (2009) Política Educativa para la Primera Infancia, Altablero 49 (FEBRERO - ABRIL 2009). Retrieved from: MEN website http://www.mineducacion.gov.co/1621/article-192210.html [Early Childhood Education Policy, our translation].

Menter, I., Brisard, E. and Smith, I. (2006) Convergence or Divergence? Initial teacher education in Scotland and England. Scotland: Dunedin Academic Press Ltd.

Mieles-Barrera, M. D., Henríquez-Linero, L. M., and Sánchez-Castellón, L. M. (2009) Identidad personal y profesional de los docentes de preescolar en el distrito de Santa Marta, Educación y Educadores, 12 (1), pp. 43-59. [Personal and professional identity of preschool teachers in the District of Santa Marta, our translation].

MinEducacion (2014) Modalidades y Condiciones de calidad para la Educación Inicial. Retrieved from: http://www.colombiaaprende.edu.co/html/familia/1597/articles341487_guia50.pdf [Modalities and Quality Conditions for Early Childhood Education, our translation].

OECD, (2016) Education in Colombia Highlights. Retrieved from: http://www.oecd.org/edu/school/Education-in-Colombia-Highlights.pdf 
Penn, H. (2005) Unequal childhoods young children's lives in poor countries. London: Routledge.

Penn, H. (2008) Understanding early childhood. Issues and controversies. Second Ed. Maidenhead: McGraw-Hill/Open University Press

Puiggrós, A. V. (2010) La hora de la soberanía educativa de América Latina, Revista Educación y Pedagogía, Medellín, Universidad de Antioquia, Facultad de Educación, 22 (58), pp. 19-28. [Time for the Educational Sovereignty in Latin America, our translation].

Ramírez, A. and T. Escorcia. (2007) La diversidad en la infancia: una mirada expedicionaria en la escuela Revista Educación y Ciudad. Colombia: IDEP. Número 13. http://www.idep.edu.co/revistas/index.php/educacion-y-ciudad/article/view/126 [Diversity in childhood: an expeditionary view in the school, our translation]. Sachs, J. (2005) Professional standards: quality teachers for the future. Paper presented at the Sharing Experience: ways forward on Standards Conference, Melbourne. Schugurensky, D. (2011) Paulo Freire. Continuum Library of Educational Thought. Series Editor: Richard Bailey, Vol 16. London, New York: Continuum Tapiero, O. (2014) Primera Infancia y Practica Formativa IV: Fantasía, Imaginación, Creación / Obras y Mundos Posibles. Unpublished document prepared for the teaching practicum professional knowledge component, Licenciatura en Pedagogia Infantil, Facultad de Educación, Universidad Distrital Francisco José de Caldas. [Early Childhood and Formative Practice IV: Fantasy, Imagination, Creation / Works and Possible Worlds, our translation].

Torres, C. A. (2008) Después de la tormenta Neoliberal: La política educativa latinoamericana entre la crítica y la Utopía, Revista Iberoamericana de 
Educación, 48, pp. 207-229. [After the Neoliberal storm: the Latin American

Educational Policy between Criticism and Utopia, our translation].

Townsend, T. (2011) Teacher education: an international perspective. Journal of Education for Teaching, 37 (4), 373-375.

United Nations (1989). Convention on the Rights of the Child. Retrieved from:

http://www.ohchr.org/EN/ProfessionalInterest/Pages/CRC.aspx

UNESCO (1998) Teachers and teaching in a changing world. Retrieved from:

http://www.unesco.org/education/information/wer/PDFeng/wholewer98.PDF

UNESCO (2006) Colombia. Early Childhood Care and Education (ECCE)

programmes. Retrieved from:

http://unesdoc.unesco.org/images/0014/001480/148094e.pdf

UNESCO (2010) Early Childhood Care and Education Regional Report. Latin America and the Caribbean. Retrieved

from: http://unesdoc.unesco.org/images/0018/001892/189212e.pdf

UNICEF and CINDE (2001) Experiencias significativas en América Latina. Retrieved from: http://www.redprimerainfancia.org/temaprioritario5.shtml?conds[0][category. $\underline{1]=001}$ [Meaningful experiences in Latin America, our translation].

United Nations (UN). (2007). Universal Declaration on the Rights of Indigenous Peoples. Retrieved from: http://www.un.org/esa/socdev/unpfii/documents/DRIPS_en.pdf

Urban, M. (2008) Dealing with uncertainty: challenges and possibilities for the early childhood profession, European Early Childhood Education Research Journal, 16 pp. 135-152. DOI: $\quad 10.1080 / 13502930802141584$.

Vanderstraeten, R. and Biesta, G. (2006) How is Education possible? Pragmatism, Communication and the Social Organization of Education, British Journal of 
Education Studies, 54(2), pp. 160-174. DOI 10.1111/j.14678527.2006.00338.x

Vegas, E. \& Santibáñez, L. (2010). The Promise of Early Childhood Development in Latin America and the Caribbean. Washington, DC: The International Bank for Reconstruction and Development / The World Bank

White, C. S. and Isenberg, J. P. (2003) 'Development Issues affecting children', in Isemberg, J. P. and Jalongo, M. (eds.) Major Trends and Issues in Early Childhood Education. New York: Teachers College Press, pp. 13-20.

World Bank (2013) Systems Approach for better Education Results. Retrieved from http://saber.worldbank.org/index.cfm 
Footnotes

1 Argentina, Bolivia, Brazil, Chile, Colombia, Costa Rica, Cuba, Dominican Republic, Ecuador, El Salvador, Guatemala, Honduras, Mexico, Nicaragua, Panama, Paraguay, Peru, Uruguay and Venezuela.

2 Original text in Spanish: ... 'acuerdos, declaraciones y tratados internacionales sobre derechos humanos ... están marcados por la asimetría abismal que separa los principios que los fundamentan de las acciones y las prácticas que deberían consagrarlos'. (Gentili, 2009, p.21).

3 Original text in Spanish: 'Sueño con una familia completa, donde reine el amor y la confianza, con una Colombia libre, con muchas escuelas grandes, de aulas amplias, bien dotadas y zonas recreativas al aire libre .... no puedo estar tranquila, porque me asaltan las preguntas: ¿hasta cuándo estaré trabajando? ¿por qué las cosas no las hacen ni limpias ni transparentes; la corrupción, el tráfico de influencias y la politiquería están acabando la educación pública'(Mieles-Barrera et al, 2009, p. 55).

4 Original text in Spanish: 'Considerar que todos ellos, independientemente del contexto sociocultural en el que crecen, tienen las capacidades para desarrollar sus competencias si encuentran un ambiente que satisface sus necesidades básicas de afecto, cuidado y alimentación' (MEN, 2009). 

Table 1: Early Childhood Development Indicators in Colombia and the Latin American Region

\begin{tabular}{|c|c|c|c|c|c|}
\hline & $\underline{\text { Colombia }}$ & $\underline{\text { Argentina }}$ & $\underline{\text { Brazil }}$ & $\underline{\text { Chile }}$ & $\underline{\text { Peru }}$ \\
\hline Infant Mortality (deaths per 1000 live births) & 17 & 12 & 17 & 8 & 15 \\
\hline Under-5 mortality (deaths per 1000 live births) & 19 & 14 & 19 & 19 & 19 \\
\hline Births attended by a skilled attendant & $98 \%$ & $98 \%$ & $97 \%$ & $100 \%$ & $84 \%$ \\
\hline Gross pre-primary enrolment rate (36-59 months, 2009) & $51 \%$ & $74 \%$ & $69 \%$ & no data & $79 \%$ \\
\hline Children below 5 with moderate/severe stunting (2006-10 & $13 \%$ & $8 \%$ & $7 \%$ & no data & $24 \%$ \\
\hline Birth registration 2000-2010 & $97 \%$ & $91 \%$ & $91 \%$ & $99 \%$ & $93 \%$ \\
\hline
\end{tabular}


Table 2: Programmes in Latin America

\begin{tabular}{|c|c|c|c|}
\hline Country & Programme & Target Group & er Served \\
\hline Argentina & Jardines Infantiles & $\begin{array}{l}\text { Children } 3-5 \text { years } \\
\text { old living in poverty }\end{array}$ & nd \\
\hline Bolivia & $\begin{array}{l}\text { Proyecto Integral de Desarollo } \\
\text { Infantil (PIDI) }\end{array}$ & $\begin{array}{l}\text { Children } 6 \text { months }-6 \\
\text { years living in poverty } \\
\text { Predominantly in urban } \\
\text { Areas }\end{array}$ & nd \\
\hline Brazil & $\begin{array}{l}\text { Programa de Atención a la } \\
\text { Población Infantil }\end{array}$ & $\begin{array}{l}\text { Children from birth - } 6 \\
\text { years at risk }\end{array}$ & 17,840 \\
\hline Chile & Crece Contigo & $\begin{array}{l}\text { All children birth }-4 \\
\text { years, especially } \\
\text { those in poverty }\end{array}$ & nd \\
\hline Colombia & $\begin{array}{l}\text { Hogares Communitarios } \\
\text { de Bienestar }\end{array}$ & $\begin{array}{l}\text { Children } 6 \text { months - } 5 \\
\text { years from SISBEN } \\
\text { families } 1 \text { and } 2\end{array}$ & 383,399 \\
\hline Cuba & 'Educa a tu Hijo' & $\begin{array}{l}\text { Boys and girls from } 6 \\
\text { years who do not attend } \\
\text { kindergartens }\end{array}$ & $*$ \\
\hline Ecuador & $\begin{array}{l}\text { PDI programa de Desarrollo } \\
\text { Infantil }\end{array}$ & $\begin{array}{l}\text { Children from } 6 \text { months } \\
\text { to } 6 \text { years whose family } \\
\text { members work outside the } \\
\text { home and do not have } \\
\text { access to adequate or } \\
\text { quality daily care }\end{array}$ & 47,000 \\
\hline Guatemala & Hogares Communitarios & $\begin{array}{l}\text { Children from birth to } 7 \\
\text { years who are at risk }\end{array}$ & 15,000 \\
\hline Mexico & Estancias y Guarderías Infantiles & $\begin{array}{l}\text { Boys and girls between } 1 \\
\text { and } 5 \text { years in which the } \\
\text { mothers or fathers or primary } \\
\text { caregiver work or are looking } \\
\text { for work }\end{array}$ & 139,302 \\
\hline Peru & Programa Nacional Wawa Wasi & $\begin{array}{l}\text { Children under } 4 \text { years } \\
\text { in poverty, with mothers } \\
\text { working outside their home }\end{array}$ & 50,000 \\
\hline Venezuela & Hogares de Cuidado diario & $\begin{array}{l}\text { Groups of }(8) \text { children under } \\
6 \text { years belonging to families } \\
\text { in the community are cared } \\
\text { for by caring mothers. }\end{array}$ & 166,971 \\
\hline
\end{tabular}

SISBEN: The Sisbén is a technical information system designed by the Colombian National Government, which allows the identification and classification of households, families and individuals, according to their needs and living conditions

* Cuba reported $99 \%$ of coverage in this Programme. 
Instituto Colombiano de Bienestar Familiar

(ICBF)

[Colombian Family

Welfare Institute]
- Materno Infantil [Mother-Child]: nutritional and health support for pregnant mothers.

- Lactantes y preescolares[Nursing mothers and pre-schoolers]

- Hogares Familia, Mujer e Infancia (FAMI) [Family, woman and childhood Homes]

- Hogares Comunitarios de Bienestar Familiar (HCBF)[ Community Family Welfare Homes]

- Madres Comunitarias [Community Mothers]

- Bienestar Grupales [Group Welfare Homes]

- Múltiple [Multiple Welfare Homes]

- Empresariales [Company Homes]

- Jardines Comunitarios [Community Kindergarten]

- Apoyo a los niños sordos [Support for Deaf Children]

- Desayunos Infantiles [Breakfast for Children]

Departamento

- Educación Inicial [Early Childhood Education]

Administrativo de

Bienestar Social del 
Distrito Capital (DABS) • Centros Amar de Integración [Integration Love Centres]

[Administrative

Department of Social

Welfare of the Capital

- Protejamos la Vida [Let's protect Life]

District]

- Nutrir para el Futuro [Nurture for the future]

Fundación Centro

- Estimulación adecuada [Adequate Stimulation]

Internacional de

Educación y Desarrollo

Humano (CINDE)

- Programa Integrado escuela-hogar [Integrated Home-School ]

[International Center for

Education and Human

Development

- Programa niño a niño [Child to Child programme]

Foundation]

- Preescolar en el hogar [Preschool at Home]

- Centros familiares comunitarios [Community Family Centres]

- Juega y aprende a pensar [Play and Learn to Think] 